\title{
TECHNOLOGIE CYFROWE W NAUCZANIU JEZYKA POLSKIEGO JAKO OBCEGO
}

\section{Słowa kluczowe: nowe media, technologie cyfrowe, glottodydaktyka}

Streszczenie. W dziedzinie edukacji rozpoczął się proces implementacji technologii informacyjnej. Nowe technologie urozmaicają proces dydaktyczny i podnoszą motywację osób uczących się. Niosą też ze sobą pewne zagrożenia. Artykuł omawia możliwości zastosowania nowych mediów w nauczaniu języka polskiego jako obcego.

Specyfikę XXI wieku oddaje dynamiczny rozwój informatyki i ekspansja Internetu. Nowoczesne technologie wkraczają z coraz większym impetem w niemal wszystkie dziedziny naszego życia. Również w obszarze edukacji rozpoczął się proces implementacji technologii informacyjnej. Od 1958 roku, kiedy to podjęto pierwsze próby zastosowania komputerów w dydaktyce (nauczanie arytmetyki binarnej), datuje się nieustanny rozwój możliwości wykorzystania tego narzędzia dla celów edukacyjnych. Dzisiaj można mówić już nie tylko o możliwościach, ale o konieczności korzystania z nowoczesnych środków w procesie dydaktycznym.

Wraz z rozwojem technik komputerowych rodziły się nowe strategie nauczania oraz nowa terminologia. Znane są dzisiaj następujące pojęcia: CAI (Computer Aided Instruction - nauczanie wspomagane komputerem), CAL (Computer Assisted Learning - uczenie się wspomagane komputerowo), CBI (Computer Based Instruction - nauczanie oparte na komputerze), CBL (Computer Based Learning - uczenie się z wykorzystaniem komputera), CDI (Computer Directed Instruction - nauczanie kierowane przez komputer), CMI (Computer Managed Instruction - nauczanie zorganizowane za pomocą komputera). W odniesieniu do nauczania języków obcych powstały następujące koncepcje: CALT (Computer Assisted Language Teaching - nauczanie języków obcych wspomagane komputerowo), MALL (Mobile Assisted Language Learning - nauka języka z wykorzystaniem

*yola@ug.gda.pl, Uniwersytet Gdański, Wydział Filologiczny, Instytut Filologii Polskiej, Katedra Polonistyki Stosowanej, ul. Wita Stwosza 51, 80-308 Gdańsk. 
technologii mobilnych) i najpopularniejsze CALL (Computer Assisted Language Learning - nauka języków obcych wspomagana komputerem) (Rachwalska-Mitas on-line, s. 156).

Rozwój nowych technologii powoduje zmiany w dydaktyce, w tym również w glottodydaktyce. Innowacje te mają przede wszystkim charakter pozytywny, ponieważ kontekst nauczania języków obcych został poszerzony o przestrzeń wirtualną. Nowe technologie urozmaicają proces nauczania i podnoszą motywację osób uczących się, wprowadzając na przykład elementy rywalizacji. Nowa wirtualna rzeczywistość dydaktyczna jest pomocna w promowaniu wiedzy i w procesie samokształcenia młodzieży oraz osób dorosłych. Niesie jednak ze sobą ogromną liczbę serwisów internetowych, stron i portali społecznościowych, platform e-learningowych poświęconych nauce języków obcych, jak również blogów, słowników, programów tłumaczeniowych, encyklopedii, wirtualnych chmur i może wywołać stres i niechęć do nowych technologii informacyjno-komunikacyjnych zarówno u nauczycieli, jak i u osób uczących się. Nauczyciele i wykładowcy zmuszeni są do samodzielnego poszukiwania informacji i wskazówek dotyczących możliwości włączenia nowych technologii w program tradycyjnych zajęć (Kaliska 2013, s. 54). Mimo licznych prac na ten temat, stanowiących próbę uporządkowania niczym nieograniczonej przestrzeni wirtualnej, trudno wyselekcjonować serwisy i aplikacje spełniające wymogi i założenia metodologii nauczania. Poza tym nowe technologie szybko przestają być innowacyjne, nudzą się bądź zostają zastąpione przez kolejne nowości, a uporządkowany i aktualny ich spis przestaje obowiązywać.

Komputer jest medium, które w glottodydaktyce może być wielostronnie wykorzystane i pozwala na wiele bardziej kompleksowe zastosowania niż tradycyjne media elektroniczne, jak wideo czy odtwarzacz CD. Techniczne możliwości przetwarzania informacji przez komputer sugerują zastosowanie go w edukacji:

- jako źródło informacji - szybkość wyszukiwania informacji staje się nieoceniona;

- jako narzędzie rozwijania umiejętności - ćwiczenia gramatyczne, stylistyczne można przeprowadzić z komputerem szybko, atrakcyjnie i efektywnie utrwalić realizowany materiał;

- jako środek nauczania poglądowego - zgodnie z zasadą nauczania poglądowego komputery skuteczniej zastępują np. kredę czy tablicę;

- jako środek symulacji i modelowania - pomoc przy odtwarzaniu procesów, zdarzeń, analizie i ocenie zdarzeń;

- jako narzędzie wypowiedzi - zastosowanie np. przy korekcie testów (Rachwalska-Mitas on-line, s. 157-158)

Nowinki techniczne są już częścią życia młodego pokolenia i dydaktyka nauczania, w tym również dydaktyka języków obcych, stara się za tymi nowinkami nadążyć, aby bardziej zainteresować i zmotywować ucznia do nauki. Oprócz 
e-maili, e-zakupów, e-pracy mamy także e-learning, czyli nauczanie przez Internet. Omówienie wszystkich narzędzi, programów i aplikacji wspierających proces glottodydaktyczny jest rzeczą niemożliwą, dlatego wybrano i krótko omówiono tylko niektóre z nich.

Tradycyjne nauczanie na odległość (korespondencyjne lub radiowe) było popularną formą kształcenia dorosłych już w latach 60. i 70. XX wieku. Jednakże upowszechnienie się Internetu przyczyniło się do tego, że uczenie na odległość zyskało nowy wymiar i zaczęło konkurować z salą wykładową (Jóźwik 2013, s. 213-214). Najpopularniejszą platformą edukacyjną służącą do nauczania zdalnego za pomocą sieci teleinformatycznych jest Moodle, czyli Modular Object-Oriented Dynamic Learning Environment. Jej twórcą jest australijski informatyk i pedagog Martin Dougiams. Pierwsza wersja platformy ruszyła w 2002 roku. Od tego czasu korzysta z niej wiele instytucji związanych z edukacją, np. uniwersytety, szkoły, prywatne przedsiębiorstwa, organizacje non-profit, szpitale, biblioteki, agencje zatrudnienia. Największą zaletą platformy jest bezpłatna dostępność i możliwość legalnego pobrania z Internetu, gdyż należy ona do tzw. produktów Open Source.

Moodle skupia 4 kategorie użytkowników. Serwisem zarządza administrator, który tworzy kursy, kategoryzuje je, sprawuje nad nimi kontrolę, sporządza listy użytkowników, wprowadza dodatkowe moduły. Drugą kategorię stanowią prowadzący i instruktorzy. Mogą oni zarządzać kursami, ale nie mogą przyznawać im kategorii, mają prawo do wprowadzania zmian do materiału kursowego, tworzenia zabezpieczeń kursu, „ręcznego” wpisywania lub skreślania z listy uczestników kursu. Trzecia grupa użytkowników platformy to nauczyciele, mogący opracowywać własne kursy i wprowadzać do nich własne treści. Czwartą kategorią są uczestnicy kursu, którzy uzyskali zgodę na uczestnictwo w zajęciach (Jóźwik 2013, s. 214).

Przykładowe kursy języka polskiego jako obcego realizowane na platformie Moodle to np. kurs organizowany przez Centrum Polonicum Uniwersytetu Warszawskiego we współpracy z COME@UW (Centrum Otwartej i Multimedialnej Edukacji UW). Również Centrum Języka i Kultury Polskiej w Świecie Uniwersytetu Jagiellońskiego oferuje kursy internetowe na uniwersyteckiej platformie Moodle, na której zamieszczane są wszystkie materiały edukacyjne. Oprócz uczelni wyższych, kursy e-learningowe realizują także firmy komercyjne, takie jak firma Edu\&More z Warszawy, która zbudowała innowacyjną platformę do nauki języka polskiego jako obcego. Długoletnim doświadczeniem dydaktycznym może pochwalić się Szkoła Języka Polskiego Glossa z Krakowa, oferująca kursy internetowe na platformie e-learningowej e-polish.eu. Bogatą ofertę kursów przez Internet dla obcokrajowców posiadają również niektóre prywatne szkoły językowe.

Glossa to portal przeznaczony zarówno dla cudzoziemców chcących się uczyć języka polskiego, jak i dla nauczycieli języka polskiego jako obcego. W zależności od preferencji można tu wybrać kurs polskiego online, lekcje indywidualne z lektorem (prowadzone przez Internet przy wykorzystaniu wirtualnej sali 
lekcyjnej) lub też zaplanować przyjazd do Polski na intensywny kurs polskiego w Krakowie i innych miastach. Na portalu e-polish.eu można znaleźć cały szereg różnorodnych materiałów, narzędzi i informacji, które pomogą lepiej poznać język polski. W zakładce Księgarnia można przejrzeć i zakupić najnowsze podręczniki, zeszyty ćwiczeń, kompendia gramatyczne i leksykalne. Znajduje się tu też multimedialny słownik, który umożliwia nie tylko sprawdzenie znaczenia słów i wyrażeń, lecz również zapoznanie się z tabelami odmian gramatycznych. Nawet, jeśli obcokrajowcy nie znają podstawowej formy słowa, słownik poradzi sobie doskonale $\mathrm{z}$ wpisanymi przez nich słowami w dowolnej formie odmiany np. książce, psa, szedtem... i pokaże uczącym się słowa książka, pies, iść... oraz thumaczenia i wszystkie informacje dotyczące danego słowa (np. ksiażce to miejscownik liczby pojedynczej rzeczownika książka, szedtem to 3. osoba liczby pojedynczej rodzaju męskiego czasu przeszłego czasownika iść). Dodatkowo przy czasownikach wyświetlana jest informacja, z jakimi przyimkami (i przypadkami) łączy się dany leksem. Ponadto dla rzeczowników i przymiotników wyświetlane są wszystkie formy deklinacji, zaś dla czasowników - odmiany w czasie teraźniejszym, przeszłym i przyszłym, formy trybu rozkazującego i przypuszczającego. Bardzo często podawane są także synonimy i antonimy do wyszukiwanego słowa oraz praktyczne przykłady jego użycia. Student może kliknąć na każdą formę odmiany, każdy przykład, synonim czy antonim i posłuchać wymowy (http:// slownik.e-polish.eu/).

Portal zatrudnia głównie nauczycieli języka polskiego, stąd duży nacisk kładziony jest na obudowę merytoryczną. W zakładce dla nauczycieli można znaleźć przykładowe materiały online do nauczania języka. Mogą to być różnego rodzaju ćwiczenia pomocne w utrwalaniu materiału gramatycznego i leksykalnego, m.in. teksty z lukami, dopasowanie słów do definicji, testy wyboru, porządkowanie zdań i wiele innych. Opublikowano tu także przejrzyste i ładnie ilustrowane zestawienia oraz tabele, porządkujące omawiane treści gramatyczne i leksykalne. Na portalu zamieszczone są również konspekty zajęć na inspirujące i dynamiczne lekcje obejmujące poziomy od A1 do B1. Można znaleźć tu także bazę nagrań $\mathrm{mp} 3$ wykonanych przez polskich aktorów. Ich wysoka jakość, naturalne brzmienie oraz zróżnicowany poziom trudności pomagają doskonalić umiejętność rozumienia języka mówionego. Niezwykle pomocne są również gry, takie jak krzyżówki, puzzle, gry planszowe, karty dialogowe, karteczki z obrazkami, hasłami czy rolami na podstawie, których należy wykonać określone zadanie komunikacyjne. Ponadto nauczyciele znajdą na portalu także ciekawy i praktyczny blog, specjalistyczne forum metodyczne oraz listę najważniejszych szkoleń i konferencji związanych z szeroko pojętą tematyką nauczania języka polskiego jako obcego.

Niestety korzystanie z portalu wiąże się z uiszczeniem opłaty. Dla tych, który z korzystają z książek z serii POLSKI krok po kroku, dostęp jest czasowo bezpłatny. Wystarczy wpisać przy logowaniu kod, mieszczący się na końcu każdego podręcznika pod płytą CD mp3 (https://e-polish.eu/). 
Kolejne internetowe narzędzie glottodydaktyczne to strona Insta.Ling, służąca do nauki słówek języka angielskiego, niemieckiego, hiszpańskiego oraz ortografii języka polskiego. Nauczyciel przydziela słówka z realizowanego w szkole materiału, a uczniowie razem z Insta.Ling powtarzają je w domu. Nauczyciel i rodzice dostają szczegółowe raporty o systematyczności pracy ucznia i jego postępach. Uczestnictwo w programie Insta.Ling dla szkół daje bezpłatny dostęp do systemu dla nauczyciela, uczniów i rodziców. Nauczyciel powinien przynajmniej raz w tygodniu przydzielić słówka dla każdej klasy oraz sprawdzić systematyczność pracy i postępy uczniów. Zwykle zajmuje to do 30 minut. Uczniowie powinni codziennie wykonywać jedną sesję nauki, która trwa około 5 minut. Szczegółowy zakres prac opisany jest w podręczniku metodycznym, który otrzymuje każdy zarejestrowany nauczyciel (https://instaling.pl/).

Blogi najczęściej kojarzone są z miejscem prywatnych wyznań i autokreacji. Tymczasem mogą stać się wielozadaniowymi narzędziami edukacyjnymi służącymi wymianie informacji o każdej porze i w dowolnym miejscu, kreującymi sieć wzajemnych powiązań i interakcji między użytkownikami oraz dającymi możliwości otwartego, nieograniczonego dzielenia się swoją twórczością, wiedzą, przemyśleniami. W Internecie możemy znaleźć już całkiem sporo blogów poświęconych nauczaniu języka polskiego jako obcego.

Jednym z nich jest Lektorka na tropie (https://jezykpolskijakoobcy.wordpress.com/) - blog Iwony Głowackiej dla nauczycieli jpjo. Znaleźć tu można wiele pomysłów, scenariuszy lekcji i ćwiczeń. Istnieje od 2015 roku i cieszy się dużą popularnością, o czym świadczy licznik pobrań. Niektóre materiały dydaktyczne są płatne. Kontynuacją bloga jest strona iwonaglowacka.com oraz profil lektorki na Facebooku.

Ciekawym blogiem, w którym znaleźć można materiały do pobrania, propozycje narzędzi multimedialnych do pracy z cudzoziemcami, a także porady i wskazówki jest Glottostrefa (https://glottostrefa.wordpress.com/). Blog powstał jako efekt pracy studentów glottodydaktyki - pasjonatów, którzy chcą się dzielić swoim glottodydaktycznym dorobkiem.

Napolskuj! (https://napolskuj.wordpress.com/) jest blogiem Ewy Grzelak, na którym autorka udostępnia bezpłatnie scenariusze pojedynczych lekcji, które mogą stać się ciekawym urozmaiceniem lekcji języka polskiego. Inne interesujące blogi dla nauczycieli języka polskiego to wspomniany wcześniej blog Glossy (https://e-polish.eu/blog/), Polski na czasie (http://polskinaczasie.pl/), blog Poli Centrum (http://www.poli.edu.pl/pl/category/blog/).

Niezwykle przydatne w dydaktyce nauczania języka polskiego są bezpłatne platformy do przeprowadzania i tworzenia interaktywnych quizów. Niewątpliwą zaletą tworzonych na nich testów jest możliwość wykorzystania potencjału urządzeń mobilnych, którymi dysponują uczniowie/studenci/kursanci, takich, jak telefony czy tablety, za pomocą których mogą oni odpowiadać na pytania zawar- 
te w teście. Narzędzia te są intuicyjne, proste w obsłudze, zatem przygotowanie quizu nie wymaga poświęcenia zbyt wiele czasu.

Pierwszą tego typu aplikacją był Kahoot (https://kahoot.it/), który do dzisiaj jest jednym z najbardziej popularnych quizów elektronicznych sprawdzających wiedzę uczniów. Jego atutem jest ogromna baza gotowych quizów z różnych przedmiotów, które można wykorzystać na zajęciach. Konkurencją Kahoota jest podobny do niego Quizzis (https://quizizz.com/), gdzie uczniowie tak samo logują się za pomocą wygenerowanego pinu, podając swoje imię. Uczestnicy elektronicznego testu widzą bezpośrednio na swoich mobilnych urządzeniach pytania quizu, bez koniczności spoglądania na komputer nauczyciela. Pytania są wymieszane przez system, co utrudnia uczniom „współpracę" przy udzielaniu prawidłowych odpowiedzi. Na koniec każdego quizu/sprawdzianu nauczyciel otrzymuje zestawienie, które także może pobrać w formie pliku Excel i jest ono dużo bardziej przejrzyste niż w Kahoocie. Po zakończonym quizie uczestnik widzi na swoim ekranie zbiór wszystkich swoich odpowiedzi wraz z podanymi prawidłowymi odpowiedziami. Podczas trwania quizu nauczyciel cały czas śledzi postępy uczniów na swoim koncie i ekranie. Gdy czas się skończy - pytanie nie znika, można jeszcze udzielić odpowiedzi, ale wówczas za prawidłową odpowiedź uzyskuje się mniej punktów. Liczy się zatem nie tylko wiedza, ale również refleks. Inne tego typu aplikacje to Mentimeter (https://www.mentimeter.com/), Socrative (https://www.socrative.com/) oraz Quizlet (https://quizlet.com/pl).

Quizlet to nie tylko aplikacja dająca możliwość tworzenia quizów, ale również doskonała strona pomagająca rozwijać kompetencje lingwistyczne za pomocą fiszek z dźwiękiem. Na stronie można korzystać z gotowych zestawów, a także samemu tworzyć nowe. Oprócz tradycyjnych fiszek aplikacja generuje ze stworzonego zestawu gry, testy, dyktanda i system do samodzielnej nauki. Jest to więc także świetny sposób dla uczniów, aby przygotowywać się do kartkówek, testów lub sprawdzianów. Quizlet daje też możliwość stworzenia przez nauczyciela wirtualnej klasy i dodawania do niej członków.

Kolejnym przydatnym narzędziem dla glottodydaktyka może być niemiecki serwis LearningApps (https://learningapps.org/). Jest to projekt badawczo-rozwojowy Pädagogische Hochschule PHBern, tworzony we współpracy z Johannes Gutenberg University of Mainz i Hochschule Zittau/Görlitz. Serwis istnieje od 2011 roku i jest dostępny w 21 językach (Czarniecka 2017). Jest to darmowa, prosta i intuicyjna $\mathrm{w}$ obsłudze platforma, umożliwiająca tworzenie (oraz użytkowanie, współdzielenie i publikowanie) gier edukacyjnych (quizy, milionerzy, wykreślanka słowna, puzzle, tabele, mapy, obrazki, memory w różnych wersjach, wisielec, krzyżówka, tekst z lukami, uzupełnienie tabeli itp.). Platforma jest wielojęzyczna i można tu znaleźć także język polski.

Niezwykle popularne w edukacji stały się ostatnio wirtualne klasy i wirtualne tablice. Susan Ko i Steve Rossen definiują wirtualną klasę następująco: „miej- 
sce w sieci, gdzie instruktorzy i studenci $<<$ spotykają się >>, dzięki połączeniom komputerowym, w celu realizacji zadań kursowych" (Rzeźnik on-line). Na wirtualnych tablicach można umieszczać wiadomości i materiały dydaktyczne. Jedną z najbardziej znanych tablic jest Padlet (https://pl.padlet.com/) - bezpłatna aplikacja sieciowa, której wykorzystanie zależy od pomysłowości jej twórcy. Wirtualne tablice mogą wspomagać pracę zespołową, promować działania placówki, stanowić miejsce dyskusji oraz wymiany notatek i materiałów. Aplikacja daje możliwość umieszczania postów w formie: linków do stron internetowych, notatek, filmów lub plików w różnych formatach (np. prezentacji). Wirtualną tablicę możemy udostępniać poprzez podanie zainteresowanym osobom unikatowego adresu URL, jak też osadzenie jej na blogu lub stronie internetowej.

Podobne funkcje pełni Classroom. Jest to bezpłatna usługa internetowa dla szkół, organizacji non-profit i osób korzystających z osobistych kont Google. Classroom ułatwia uczniom i nauczycielom komunikowanie się między sobą, zarówno w szkole, jak i poza nią, publikowanie ogłoszeń, co ułatwia przekazywanie ważnych informacji i funkcjonuje jako ,przypominacz" o istotnych sprawach. Można też tworzyć zadania, dołączać do nich materiały, wystawiać oceny, a potem zwracać je uczniom. Kiedy nauczyciel utworzy zadanie, wszyscy uczniowie przypisani do danej klasy otrzymają e-mail z powiadomieniem, a także zobaczą informację o nowym zadaniu $\mathrm{w}$,strumieniu zajęć”. Jest to z punktu widzenia nauczyciela bardzo wygodne narzędzie, gdyż za jednym kliknięciem można wysłać pracę domową wszystkim uczniom (Rumiński 2015).

Kolejną bezpłatną platformą przeznaczoną do gromadzenia, organizowania i udostępniania materiałów edukacyjnych jest Blendspace (https://www.tes.com/ lessons). Materiały w formie filmów, zdjęć, notatek, linków do stron internetowych lub plików możemy zamieścić w e-lekcjach, które mogą mieć status prywatny lub publiczny. Plusem blendspace jest możliwość zespołowej pracy nad „lekcją”. Z perspektywy nauczyciela, warto podkreślić możliwość tworzenia nieograniczonej liczby wirtualnych klas (w każdej z nich może być 35 uczniów) oraz monitorowania postępów uczniów za pomocą wbudowanych w aplikację quizów (Szeląg on-line).

Inne wirtualne tablice służące do pracy zespołowej to np. Trello (https://trello.com/), Edmodo (https://www.edmodo.com/), Scriblink (http://www.pearltrees. com/u/704293-scriblink-online-whiteboard). Każda z nich oferuje podobne funkcje i jest doskonałym narzędziem mogącym uatrakcyjnić lekcje języka polskiego jako obcego.

Do technologii cyfrowych, które wspomagają rozwój kompetencji lingwistycznych zaliczyć należy również aplikacje na telefony komórkowe. Programy tego typu, z jednej strony są dobrym rozwiązaniem, gdyż dzięki nim można uczyć się języka obcego wszędzie i o każdej porze dnia, np. siedząc w tramwaju lub idąc do pracy. Z drugiej jednak strony nie wszystkie aplikacje mobilne do nauki języka 
polskiego zasługują na zaufanie użytkowników. Wśród sporej liczby androidowych programów do nauki słówek znaleźć można Ucz Się Polski Słownictwo. Pełen błędów składniowych i gramatycznych opis reklamujący aplikację zdaje się być żywym tłumaczeniem z internetowego słownika, ale jego twórcy lojalnie uprzedzają użytkowników, że można się tam nauczyć tylko słownictwa i wyrażeń, a do nauki gramatyki zaleca się udział w kursie językowym. Inne aplikacje na urządzenia mobilne, za pomocą których można uczyć się leksyki i fonetyki, rozwiązywać quizy to np. Polski dla obcokrajowców, Learn Polish, Speak Polish, dla dzieci i początkujących Uczymy się i bawimy. Polskie stówka - Stownictwo oraz Nauka polskiego - 5000 zwrotów.

Niezwykle przydatne w pracy nauczyciela języka polskiego jako obcego są znane gry typu chmura słów, dobble czy koło fortuny. Każdą z tych gier nauczyciel może sam wygenerować w wersji elektronicznej i zamieścić w niej omawiany materiał dydaktyczny, który w przyjemny i ciekawy sposób będzie przyswajany przez uczniów. Gry tego typu wyzwalają kreatywność, pobudzają wyobraźnię, inspirują oraz uczą krytycznego myślenia. Uatrakcyjniają lekcje, a nudne do tej pory zadania zaczynają sprawiać frajdę. Generatory, które służą do tworzenia gier, są przyjazne, proste i łatwe w użyciu i bezpłatne. Proces ich tworzenia nie zajmuje wiele czasu. $\mathrm{Z}$ powodzeniem można je stosować na każdym etapie edukacji.

Przykładowe generatory chmury słów: Wordart, Wordle, Tagxedo, Tagul, TagCrowd, ABcya, WordSift, ImageChef, WordItOut. Aplikacje te działają na podobnych zasadach, ale często mają różne funkcje, ustawienia oraz możliwości edycji (limity słów, czcionki, wielkości, kształty). Warto przetestować i wybrać swój ulubiony program. Dobblemania (https://dobblemania.pl/) to generator gry dobble, którą można wykorzystać do utrwalania słownictwa. Koło fortuny natomiast może być przydatne nie tylko do zapamiętywania słówek, ale także do odmian wylosowanego czasownika, układania pytań lub przeczeń do wylosowanych zdań i wielu innych działań edukacyjnych. Grę tę można zastosować na każdej lekcji - wystarczy mieć komputer z dostępem do Internetu oraz rzutnik. Generatory tej gry to np. Wheeldecide (http://wheeldecide.com/) czy Random Name Picker (https://www.classtools.net/random-name-picker/) ${ }^{1}$.

Rozwój kompetencji lingwistycznych jest procesem złożonym i bardzo długotrwałym, wymagającym wielu ćwiczeń. Jest to często żmudna praca zarówno dla nauczyciela, jak i dla uczniów, którzy łatwo popadają w zniechęcenie. Dlatego chcąc wspierać rozwój sprawności komunikacyjnych, nie można się ograniczyć do celów kognitywnych, ale trzeba również zadbać o sferę emocjonalną i społeczną osobowości ucznia.

${ }^{1}$ Więcej informacji na temat narzędzi promujących wykorzystanie nowych technologii w glottodydaktyce można znaleźć np. w dziale Nowe technologie w cyfrowej wersji w czasopiśmie „Języki Obce w Szkole". 
Technologie cyfrowe w rozwijaniu kompetencji lingwistycznych najbardziej trafiają do młodych ludzi, tzw. cyfrowych tubylców, którzy stanowią nowe pokolenie urodzone w dobie powszechnej komputeryzacji i wirtualnej globalizacji. Jest to dla nich naturalne środowisko, gdyż umiejętności posługiwania się nowoczesnym sprzętem i aplikacjami komputerowymi zdobyli już w okresie przedszkolnym lub wczesnoszkolnym. Ich życie często rozgrywa się również w rzeczywistości wirtualnej, przez co chętnie sięgają po programy przeznaczone do nauki.

Wdrażanie nowych technologii w proces glottodydaktyczny uzależnione jest od poziomu kompetencji medialnej nauczycieli języka polskiego jako obcego. Składają się na nią:

- umiejętności techniczne (kompetencja techniczna),

- wiedza na temat materiałów edukacyjnych dostępnych w sieci i umiejętność ich doboru oraz selekcji (kompetencja semantyczna),

- wiedza na temat celowego zastosowania dostępnych za pomocą mediów materiałów, zgodnie $\mathrm{z}$ ich przeznaczeniem i w odniesieniu do istniejących potrzeb (kompetencja pragmatyczna) (Prizel-Kania 2017, s. 91).

Możliwości, jakie stwarzają nowe technologie, wykorzystywane są często tylko jako źródło tekstów, nagrań audio-wideo oraz materiałów graficznych. Lektorzy języka polskiego jako obcego owszem wykorzystują zasoby sieciowe, ale nie korzystają z TIK w celu przygotowania interaktywnych ćwiczeń językowych lub zadań wymagających interakcji pomiędzy uczącymi się. O włączeniu do nauczania wspomagania komputerowego decyduje nauczyciel, a punktem odniesienia jest tu jego własna wiedza merytoryczna, która nie zawsze jest wystarczająca (Prizel-Kania 2017, s. 91).

Nowe media z pewnością urozmaiciły i poszerzyły kontekst dydaktyczny. Trudno jednak powiedzieć, czy zmieniły możliwości przyswajania wiedzy i rozwijania umiejetności. Mimo wielu pozytywów, wynikających z wykorzystania technologii cyfrowych w glottodydaktyce, zastosowanie komputerów w edukacji wiąże się też z pewnymi zagrożeniami. Nadmiar bodźców może wpłynąć na brak koncentracji osób uczących się, a zbyt częste wykorzystanie technologii cyfrowych, jak każda rzecz powszechnie stosowana, z czasem może stać się po prostu nudna i mało efektywna. Zawsze też istnieje prawdopodobieństwo awarii sprzętu komputerowego, braku połączenia z Internetem czy styczności z tzw. uczniem „wykluczonym cyfrowo". 


\section{BIBLIOGRAFIA}

Jóźwik K., 2013, Nauczanie języka polskiego jako obcego przez Internet na przykładzie kursu dla obcokrajowców na poziomie A1, w: J. Mazur, A. Małyska, K. Sobstyl (red.), Glottodydaktyka polonistyczna w obliczu dynamiki zmian językowo-kulturowych i potrzeb społecznych. t. 2., Lublin, s. 213-218.

Kaliska M., 2013, Tablety i smartfony: nowe narzędzia glottodydaktyczne, „Lingwistyka Stosowana", $\mathrm{nr} 8$, s. 54-66.

Prizel-Kania A., 2017, Nauczanie języka polskiego jako obcego wspomagane komputerowo- badanie opinii nauczycieli [online], http://jows.pl/sites/default/files/prizel-kania.pdf [10.06.2018].

Rachwalska-Mitas M., Analiza możliwości zastosowań komputera w nauce języka polskiego na wyższych studiach technicznych [online], http://www.kms.polsl.pl/prv/spnjo/referaty/rachwalska-mitas.pdf [13.06.2018].

Rumiński Ł., 2015, Jak radzić sobie z nadmiarem makulatury, [online] http://www.superbelfrzy. edu.pl/pomyslodajnia/google-classroom/ [13.06.2018].

Rzeźnik M., Nauczanie w klasie wirtualnej i tradycyjnej-porównanie, [online], http://www.e-edukacja.net/_referaty/8_e-edukacja.pdf [13.06.2018].

Szeląg A., Udostępnianie materiałów edukacyjnych w Blendspace, [online], http://moodle.wmbp. edu.pl/course/index.php?categoryid=12 [13.06.2018].

\section{Jolanta Laskowska}

\section{DIGITAL TECHNOLOGIES IN THE DEVELOPMENT OF LINGUISTIC COMPETENCES}

Keywords: new media, digital technologies, glottodidactics

Abstract. In the field of education, the process of implementing information technology has begun. New technologies diversify the didactic process and increase the motivation of students. They also carry certain risks. The article presentsd selected possibilities of using new media in teaching foreign languages, mainly Polish as foreign language. 